\title{
Validity of Urinary Monoamine Assay Sales Under the "Spot Baseline Urinary Neurotransmitter Testing Marketing Model” [Retraction]
}

Hinz M, Stein A, Uncini T. Int J Nephrol Renovasc Dis. 2011;4:101-113.

The Editor-in-chief and Publisher of International Journal of Nephrology and Renovascular Disease wish to retract the published article.

This review article cites several original research articles published by the authors, which have recently been retracted. This article draws on the findings from those original research articles to form central arguments and discussion, and as a result of the research articles' retraction, the argument presented in this article is no longer valid and the editor has determined it should be retracted.

Our decision-making was informed by our policy on publishing ethics and integrity and the COPE guidelines on retraction.

The retracted article will remain online to maintain the scholarly record, but it will be digitally watermarked on each page as "Retracted".

\section{Publish your work in this journal}

The International Journal of Nephrology and Renovascular Disease is an international, peer-reviewed open-access journal focusing on the pathophysiology of the kidney and vascular supply. Epidemiology, screening, diagnosis, and treatment interventions are covered as well as basic science, biochemical and immunological studies. The manuscript management system is completely online and includes a very quick and fair peer-review system, which is all easy to use. Visit http://www.dovepress.com/testimonials.php to read real quotes from published authors. 